\title{
NUMERICAL ANALYSIS OF THIN-WALLED PURLINS RESTRAINED BY SHEETING IN ELEVATED TEMPERATURE CONDITIONS
}

\section{K. RZESZUT ${ }^{1}$, L. POLUS ${ }^{2}$}

\begin{abstract}
The paper presents an analysis of the influence of elevated temperature on thin-walled purlins restrained by sheeting. In the first part of the study the bearing capacity of purlins cooperating with sheeting is examined in normal and elevated temperature based on European Standards. Next, special attention is paid to creating a numerical FEM model of the restrained purlins in Abaqus program taking into account different materials properties with respect to temperature increase.
\end{abstract}

Keywords: fire load conditions, thin-walled purlins, trapezoidal sheeting, numerical analysis

\section{INTRODUCTION}

The primary responsibility of designers is to ensure the safety of people and materials located in buildings in normal and fire conditions [1]. The conservative and the advanced design methods in fire conditions are widely discussed in [2]. Designers can easily determine the critical temperature and the fire resistance time of an element using the recommendation contained in [4]. In civil engineering practice, the thin-walled purlins restrained by sheeting have a variety of applications. Using this type of purlins provides several advantages. One of them is their high strength in relation to weight. Yet another advantage is a significant reduction of the costs connected with transport and erection. Nevertheless, it is a fact that thin-walled purlins demonstrate

\footnotetext{
${ }^{1}$ Ph. D., Poznan University of Technology, Faculty of Civil Engineering and Environmental Engineering, Piotrowo 5, 60-965 Poznań, Poland, e-mail: katarzyna.rzeszut@put.poznan.pl

${ }^{2}$ M. Sc., Poznan University of Technology, Faculty of Civil Engineering and Environmental Engineering, Piotrowo 5, 60-965 Poznań, Poland, e-mail: lukasz.polus@put.poznan.pl
} 
very low fire resistance. Therefore, load capacity of purlins restrained by sheeting in elevated temperature is analysed in this paper. In [4] and [7], it is recommended that for the members with class 4 cross sections the temperature $350^{\circ} \mathrm{C}$ is to be regarded as the critical temperature. It means that this kind of cross section theoretically loses its load capacity under this temperature. Maślak [9] points out that it is difficult to determine fire resistance of class 4 elements.

\section{Calculation background}

\subsection{LATERAL AND ROTATION RESTRAINT ACCORDING TO THE EN}

The lateral restraint provided by the trapezoidal sheeting generally takes the load in the plane of the sheeting. Therefore, the purlin may be regarded as being laterally restrained in plane of the sheeting and partially rotationally restrained. The rotational restraint should be modelled as rotational spring acting at the top flange of the purlin (see Fig. 1).

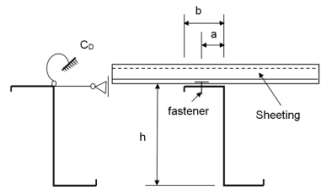

Fig. 1. Lateral and rotational restrained purlin

The simplified formula for the total rotational spring stiffness $C_{D}$ according to [5] takes the form:

$$
\mathrm{C}_{\mathrm{D}}=\frac{1}{\left(1 / \mathrm{C}_{\mathrm{D}, \mathrm{A}}+1 / \mathrm{C}_{\mathrm{D}, \mathrm{C}}\right)}
$$

where:

$\mathrm{C}_{\mathrm{D}, \mathrm{A}}$ - rotational stiffness of the connection between the sheeting and purlin, $\mathrm{C}_{\mathrm{D}, \mathrm{C}}-$ rotational stiffness corresponding to the flexural stiffness of the sheeting

The maximum stress in the cross section of the purlins should satisfy the conditions:

- in the restrained flange:

$$
\sigma_{\text {max }}=\frac{\mathrm{M}_{\mathrm{y}, \mathrm{Ed}}}{\mathrm{W}_{\text {eff,y }}}+\frac{\mathrm{N}_{\mathrm{Ed}}}{\mathrm{A}_{\text {eff }}} \leq \mathrm{f}_{\mathrm{y}} / \gamma_{\mathrm{M}}
$$


- in unrestrained flange:

$$
\sigma_{\max }=\frac{M_{y, E d}}{W_{\text {eff, }}}+\frac{N_{E d}}{A_{\text {eff }}}+\frac{M_{\mathrm{f}, E d}}{W_{\mathrm{fz}}} \leq f_{\mathrm{y}} / \gamma_{\mathrm{M}}
$$

where:

$A_{\text {eff }}-$ effective cross sections, $f_{y}-$ yield strength, $M_{\mathrm{fz}, E d}-$ bending moment in the free flange

The buckling bearing capacity of the free flange is included in the formula:

$$
\sigma_{\max }=\frac{1}{\chi_{\mathrm{LT}}} \cdot\left(\frac{\mathrm{M}_{\mathrm{y}, \mathrm{Ed}}}{\mathrm{W}_{\text {eff, }}}+\frac{\mathrm{N}_{\mathrm{Ed}}}{A_{\text {eff }}}\right)+\frac{\mathrm{M}_{\mathrm{f}, \mathrm{Ed}}}{\mathrm{W}_{\mathrm{fz}}} \leq \mathrm{f}_{\mathrm{y}} / \gamma_{\mathrm{M}}
$$

\subsection{FIRE RESISTANCE ACCORDING TO THE EN}

In order to determine the fire resistance of the purlin, the critical temperature should be calculated. The critical temperature for members with class 4 cross sections should be calculated using the iterative method [8]. When the temperature increases, the yield strength of steel and Young's modulus reduce [10]. Reduction of the yield strength for members with class 4 cross sections is greater than for members with another class [7]. The loads and their effects are also reduced under fire conditions. The bending moment in the free flange due to the lateral load should be calculated including reduction presented above. The rotational stiffness corresponding to the flexural stiffness of the sheeting in the fire situation should be calculated from [4] and [5] in the form:

$$
\mathrm{C}_{\mathrm{D}, \mathrm{C}}=\frac{\mathrm{k} \cdot \mathrm{k}_{\mathrm{E}, \theta} \cdot \mathrm{E} \cdot \mathrm{I}_{\mathrm{eff}}}{\mathrm{s}}
$$

where:

$\mathrm{k}$ - numerical coefficient, $\mathrm{I}_{\mathrm{eff}}$ - effective second moment of area per unit width of the sheeting, $\mathrm{s}$ - spacing of the purlins, $\mathrm{k}_{\mathrm{E}, \theta}-$ reduction factor for the slope of the strength linear elastic range

When the lateral spring stiffness $\mathrm{K}$ per unit length and the $\mathrm{R}_{0}$ factor are calculated, Young's modulus should be also reduced. The equivalent lateral load $\mathrm{q}_{\mathrm{h}, \mathrm{Ed}}$ should be obtained in the fire situation [4][5]:

$$
\mathrm{q}_{\mathrm{k}, \mathrm{fi}, \mathrm{Ed}}=\mathrm{k}_{\mathrm{h}} \cdot \mathrm{q}_{\mathrm{Ed}, \mathrm{ii}}
$$


where:

$\mathrm{k}_{\mathrm{h}}-$ coefficient, $\mathrm{q}_{\mathrm{Ed}, \mathrm{fi}}-$ load in the fire situation, reduced load from the normal situation

The reduction factor of lateral torsional buckling should be determined from [4] using:

$$
\chi_{\mathrm{LT}}=\frac{1}{\varphi_{\mathrm{LT}}+\sqrt{\varphi_{\mathrm{LT}}^{2}-\bar{\lambda}_{\theta, \mathrm{E}}^{2}}}
$$

The relative factor of lateral torsional buckling should be calculated in current temperature in the fire:

$$
{\overline{\lambda_{\theta, \mathrm{i}}}}_{\overline{\lambda_{\mathrm{E}}}} \sqrt{\frac{\mathrm{k}_{\mathrm{y}, \theta}}{\mathrm{k}_{\mathrm{E}, \theta}}}
$$

where:

$\mathrm{k}_{\mathrm{y}, \theta}-$ reduction factor of the yield strength of steel, $\overline{\lambda_{\mathrm{Z}}}-$ relative slenderness, $\varphi_{\mathrm{LT}}-$ coefficient

What is more, in equations (2.2), (2.3) and (2.4) the yield strength of steel should be reduced in the fire situation.

\section{Calculation eXample}

Two-spans purlin Z250x68/60x1.5mm restrained by sheeting T50x0.7mm was analysed. The effective cross section and the effective section modulus were determined in accordance with $[5,6]$ based on the material properties at $20^{\circ} \mathrm{C}$ [4]. The data used in calculation are presented in Table 1 .

\begin{tabular}{|c|c|c|c|}
\hline Data & Symbol & Value & Unit \\
\hline Steel sheeting & \multicolumn{3}{|c|}{$\mathrm{T} 50 \times 0.7 \mathrm{~mm} \mathrm{~S} 320$} \\
\hline Purlin & \multicolumn{3}{|c|}{$\mathrm{Z} 250 \times 68 / 60 \times 1.5 \mathrm{~mm} \mathrm{~S} 350$} \\
\hline Static schema of the purlin & \multicolumn{3}{|c|}{ Two-spans } \\
\hline Beam span & 1 & 4.0 & $\mathrm{~m}$ \\
\hline Distance between the purlins & $\mathrm{r}$ & 2.5 & $\mathrm{~m}$ \\
\hline Characteristic snow load & $\mathrm{q}_{\mathrm{s}}$ & 0.72 & $\mathrm{kN} / \mathrm{m}^{2}$ \\
\hline Characteristic wind load & $\mathrm{q}_{\mathrm{w}}$ & -1.08 & $\mathrm{kN} / \mathrm{m}^{2}$ \\
\hline Self-weight of roof & $\mathrm{g}$ & 0.27 & $\mathrm{kN} / \mathrm{m}^{2}$ \\
\hline Design normal force in normal condition & $\mathrm{N}_{\mathrm{Ed}}$ & 15.0 & $\mathrm{kN}$ \\
\hline Ratio which reduces the loads and effects in the fire situation & $\eta_{\mathrm{fi}}$ & 0.65 & - \\
\hline Effective section modulus, gravity load & $\mathrm{W}_{\text {eff }}$ & 31.11 & $\mathrm{~cm}^{3}$ \\
\hline Effective area of cross section, gravity load & $\mathrm{A}_{\text {eff }}$ & 4.88 & $\mathrm{~cm}^{2}$ \\
\hline Effective section modulus, uplift load & $\mathrm{W}_{\text {eff }}$ & 30.39 & $\mathrm{~cm}^{3}$ \\
\hline Effective area of cross section, uplift load & $\mathrm{A}_{\mathrm{eff}}$ & 4.61 & $\mathrm{~cm}^{2}$ \\
\hline Elastic section modulus of the free flange & $\mathrm{W}_{\mathrm{fz}}$ & 1.04 & $\mathrm{~cm}^{3}$ \\
\hline
\end{tabular}

Table 1. The data 
The critical temperature for members with class 4 cross sections was calculated using the iterative method. The temperature influence on the stiffness, the yield strength and ULS is presented in Table 2.

Table 2. The calculation

\begin{tabular}{|c|c|c|c|c|c|c|}
\hline \multirow{2}{*}{ Parameter } & \multirow{2}{*}{$\stackrel{\mathscr{\Xi}}{\breve{\Xi}}$} & \multirow{2}{*}{ Loading } & \multicolumn{4}{|c|}{ Temperature } \\
\hline & & & $20^{\circ} \mathrm{C}$ & $350^{\circ} \mathrm{C}$ & $400^{\circ} \mathrm{C}$ & $420^{\circ} \mathrm{C}$ \\
\hline \multirow{2}{*}{$\begin{array}{l}\text { Total rotational spring } \\
\text { stiffness }\end{array}$} & \multirow[t]{2}{*}{$\mathrm{C}_{\mathrm{D}}$} & Gravity & $1.81 \mathrm{kNm} / \mathrm{m}$ & $1.64 \mathrm{kNm} / \mathrm{m}$ & $1.64 \mathrm{kNm} / \mathrm{m}$ & $1.68 \mathrm{kNm} / \mathrm{m}$ \\
\hline & & Uplift & $0.78 \mathrm{kNm} / \mathrm{m}$ & $0.75 \mathrm{kNm} / \mathrm{m}$ & $0.76 \mathrm{kNm} / \mathrm{m}$ & $0.76 \mathrm{kNm} / \mathrm{m}$ \\
\hline \multirow{2}{*}{$\begin{array}{c}\text { Total lateral spring } \\
\text { stiffness }\end{array}$} & \multirow[t]{2}{*}{$\mathrm{K}$} & Gravity & $0.0107 \mathrm{Nmm} / \mathrm{m}$ & $0.0082 \mathrm{Nmm} / \mathrm{m}$ & $0.0078 \mathrm{Nmm} / \mathrm{m}$ & $0.0079 \mathrm{Nmm} / \mathrm{m}$ \\
\hline & & Uplift & $0.0107 \mathrm{Nmm} / \mathrm{m}$ & $0.0082 \mathrm{Nmm} / \mathrm{m}$ & $0.0077 \mathrm{Nmm} / \mathrm{m}$ & $0.0079 \mathrm{Nmm} / \mathrm{m}$ \\
\hline \multirow{2}{*}{$\begin{array}{l}\text { Coefficient of the spring } \\
\text { support }\end{array}$} & \multirow[t]{2}{*}{$\mathrm{R}$} & Gravity & 1.41 & 1.40 & 1.43 & 1.41 \\
\hline & & Uplift & 1.41 & 1.40 & 1.43 & 1.41 \\
\hline \multirow{2}{*}{$\begin{array}{l}\text { Correction factor for the } \\
\text { effective spring support }\end{array}$} & \multirow[t]{2}{*}{$\kappa_{R}$} & Gravity & 0.67 & 0.67 & 0.67 & 0.67 \\
\hline & & Uplift & 0.75 & 0.75 & 0.75 & 0.75 \\
\hline \multirow[t]{2}{*}{ Coefficient } & \multirow[t]{2}{*}{$\mathrm{k}_{\mathrm{h}}$} & Gravity & 0.10 & 0.1 & 0.10 & 0.10 \\
\hline & & Uplift & -0.04 & -0.04 & -0.04 & -0.04 \\
\hline \multirow[t]{2}{*}{ Equivalent lateral load } & \multirow[t]{2}{*}{$\mathrm{q}_{\mathrm{h}, \mathrm{Ed}}$} & Gravity & $0.374 \mathrm{kN} / \mathrm{m}$ & $0.243 \mathrm{kN} / \mathrm{m}$ & $0.243 \mathrm{kN} / \mathrm{m}$ & $0.243 \mathrm{kN} / \mathrm{m}$ \\
\hline & & Uplift & $0.130 \mathrm{kN} / \mathrm{m}$ & $0.080 \mathrm{kN} / \mathrm{m}$ & $0.080 \mathrm{kN} / \mathrm{m}$ & $0.080 \mathrm{kN} / \mathrm{m}$ \\
\hline \multirow[t]{2}{*}{ Lateral bending moment } & \multirow[t]{2}{*}{$\mathrm{M}_{\mathrm{fz}, \mathrm{Ed}}$} & Gravity & $-0,501 \mathrm{kNm}$ & $-0.325 \mathrm{kNm}$ & $-0.325 \mathrm{kNm}$ & $-0.325 \mathrm{kNm}$ \\
\hline & & Uplift & $0.17 \mathrm{kNm}$ & $0.12 \mathrm{kNm}$ & $0.12 \mathrm{kNm}$ & $0.12 \mathrm{kNm}$ \\
\hline Relative slenderness & $\overline{\lambda_{\theta}}$ & Uplift & 0.93 & 0.90 & 0.89 & 0.86 \\
\hline Reduction factor & $\chi_{\mathrm{LT}}$ & Uplift & 0.64 & 0.54 & 0.55 & 0.56 \\
\hline \multirow[t]{2}{*}{ Normal force } & \multirow[t]{2}{*}{$\mathrm{N}_{\mathrm{Ed}}$} & Gravity & $15.0 \mathrm{kN}$ & $9.75 \mathrm{kN}$ & $9.75 \mathrm{kN}$ & $9.75 \mathrm{kN}$ \\
\hline & & Uplift & $15.0 \mathrm{kN}$ & $9.75 \mathrm{kN}$ & $9.75 \mathrm{kN}$ & $9.75 \mathrm{kN}$ \\
\hline \multirow[t]{2}{*}{ Bending moment } & \multirow[t]{2}{*}{$\mathrm{M}_{\mathrm{y}, \mathrm{Ed}}$} & Gravity & $7.28 \mathrm{kNm}$ & $4.73 \mathrm{kNm}$ & $4.73 \mathrm{kNm}$ & $4.73 \mathrm{kNm}$ \\
\hline & & Uplift & $3.57 \mathrm{kNm}$ & $2.32 \mathrm{kNm}$ & $2.32 \mathrm{kNm}$ & $2.32 \mathrm{kNm}$ \\
\hline Yield strength & $f_{y, \theta}$ & $\begin{array}{c}\text { Gravity } \\
\text { and } \\
\text { Uplift }\end{array}$ & $350.0 \mathrm{MPa}$ & $252.0 \mathrm{MPa}$ & $228.0 \mathrm{MPa}$ & $217.0 \mathrm{MPa}$ \\
\hline \multirow[t]{2}{*}{ Stresses } & \multirow[t]{2}{*}{$\sigma$} & Gravity & $264.8 \mathrm{MPa}$ & 203.0MPa & 203.0MPa & 203.0MPa \\
\hline & & Uplift & $236.3 \mathrm{MPa}$ & $216.0 \mathrm{MPa}$ & $216.0 \mathrm{MPa}$ & $216.0 \mathrm{MPa}$ \\
\hline \multirow[t]{2}{*}{ Degree of utilisation } & \multirow[t]{2}{*}{-} & Gravity & $76 \%$ & $81 \%$ & $89 \%$ & $94 \%$ \\
\hline & & Uplift & $68 \%$ & $86 \%$ & $95 \%$ & $99 \%$ \\
\hline
\end{tabular}

Degree of utilization of the purlin depending on the temperature is presented in Figure 2. It was found that the $420^{\circ} \mathrm{C}$ is the critical temperature after which the purlin loses its bearing capacity. 


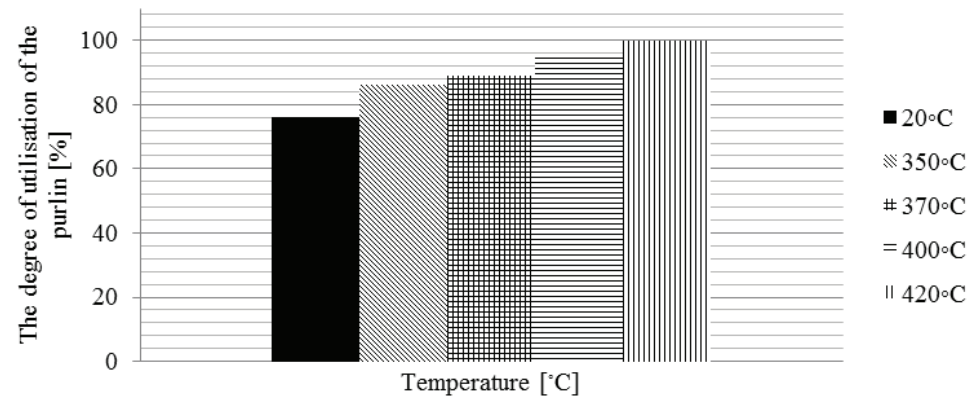

Fig. 2. The degree of utilization of the purlin depending on the temperature

\section{NUMERICAL MODEL}

To study the influence of restraint realized by sheeting on bearing capacity of a thin-walled purlin an advanced FEM model using the shell elements S4R is created. The numerical model reflects an intermediate segment of a light-weight roof and consists of trapezoidal sheeting and two thinwalled Z-purlins (see Fig. 3).

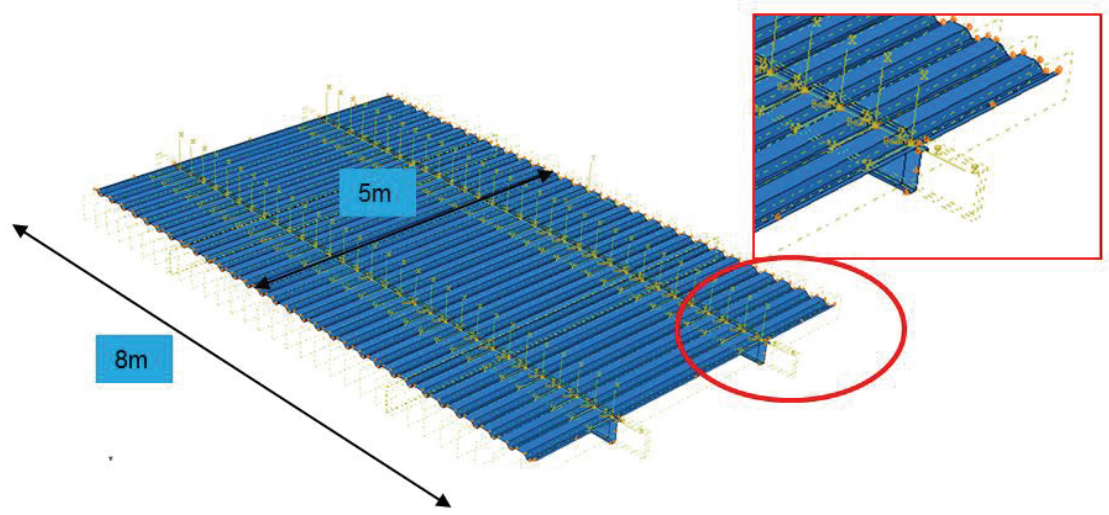

Fig. 3. The overall dimensions and the boundary conditions of the sheeting

Purlins are restrained by trapezoidal sheeting. The sheeting is connected to the purlins using special connectors modelled as the "beam connector" type (see Fig. 4). 


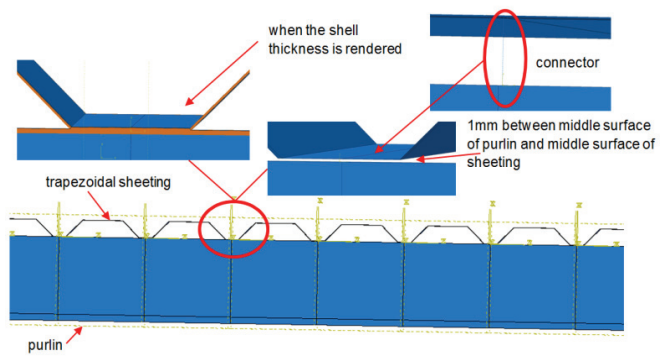

Fig. 4. A connector which join sheeting and a purlin

Connectors connect middle surfaces of trapezoidal sheeting and Z-purlins. Between sheet and purlins a surface to surface "hard" contact is defined (see Fig. 5).

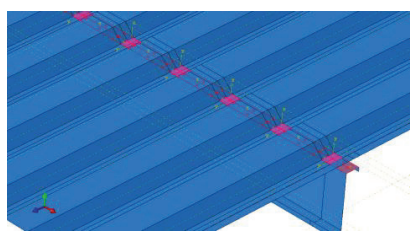

Fig. 5. A surface to surface "hard" contact

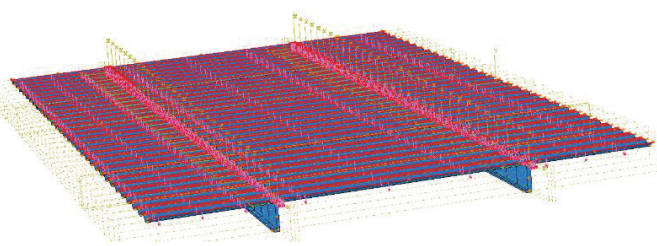

Fig. 6. Gravity load

External load is applied to the top surface of trapezoidal sheeting with parallel direction to gravity (gravity load case) (see Fig. 6) and with perpendicular direction to the sheeting (uplift load case). There are also normal forces which are generated using displacements $\left(u_{1}>0\right)$ (see Fig. 7). The calculations were performed using the Abaqus-Standard program and the Newton-Raphson method.

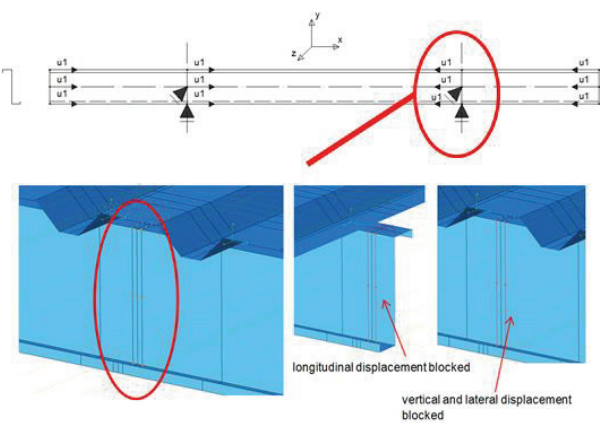

Fig. 7. Boundary conditions of the purlin, $\mathrm{u}_{1}>0$

Elasto-plastic material models were used. The laws of physics for each material and temperatures are shown in the figure below. 


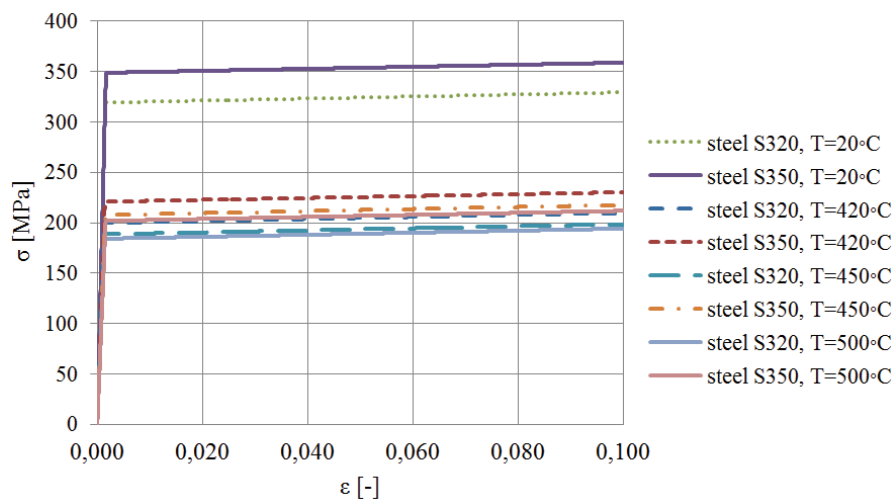

Fig. 8. Steel $\mathrm{S} 350$ and $\mathrm{S} 320, \mathrm{~T}=20^{\circ} \mathrm{C}, 420^{\circ} \mathrm{C}, 450^{\circ} \mathrm{C}, 500^{\circ} \mathrm{C}$

The criterion of purlin failure is assumed as beginning of the material plastification. The model does not include instability, which could occur earlier than plastification. What is more, temperature has influence only on the material's properties in this model and do not induce any internal forces. The model does not contain influence of the temperature on boundary conditions too. Therefore in the next study, more accurate model of the structure should be prepared. Among the other, the improved model should take into account the fact that connection between sheeting and a purlin may be destroyed in the fire situation.

\section{Numerical Calculation Results}

As a result of the numerical calculation the map of stresses was obtained. The failure mode was assumed when the plastic stresses appeared in the purlin. The stresses in the sheeting and the purlin at the temperature $500{ }^{\circ} \mathrm{C}$ are presented in the figure below.

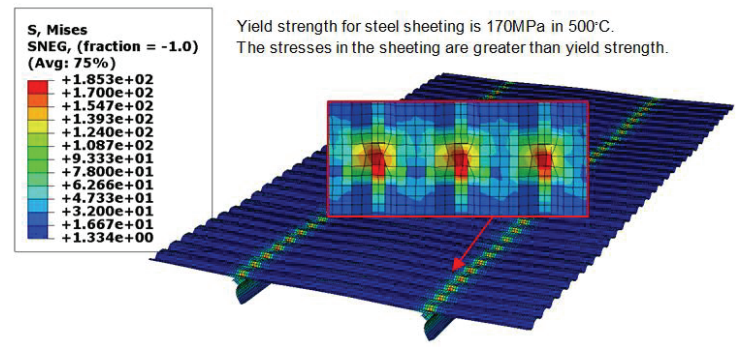

Fig. 9. The stresses in the sheeting at the temperature $500{ }^{\circ} \mathrm{C}$ in uplift load case 


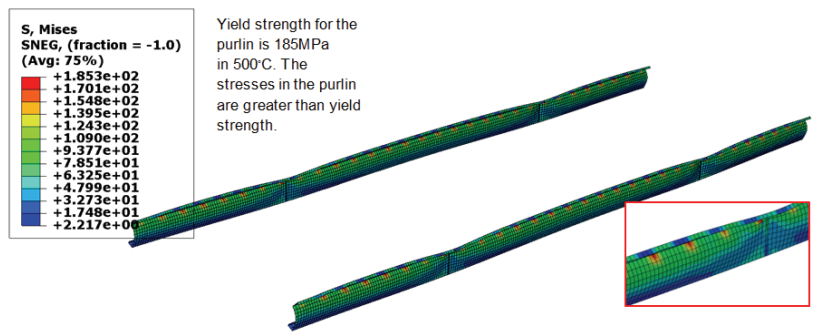

Fig. 10. The stresses in the purlin at the temperature $500{ }^{\circ} \mathrm{C}$ in uplift load case

One can notice that the sheeting and the purlin were plasticized and the purlin loses the load capacity when the temperature reaches $500{ }^{\circ} \mathrm{C}$.

\section{CONCLUSION REMARKS}

In the paper the influence of elevated temperatures on thin-walled purlins restrained by sheeting was analyzed. In a first part of the study the bearing capacity of purlins cooperating with sheeting was examined based on European Standards in normal and elevated temperatures. Next, the advanced FEM, shell model which reflects an intermediate segment of a light-weight roof was created. Thanks to modification in the formulas EN 1993$1-3$, it was possible to find the bearing capacity of a purlin under a fire situation. The yield strength of steel, Young's modulus and the loads were reduced. Based on the analysis it was found that for example, under consideration, the critical temperature reached $500{ }^{\circ} \mathrm{C}$ using a numerical FEM model and the $420{ }^{\circ} \mathrm{C}$ using the standard iterative procedure. At this temperature the trapezoidal sheeting and the purlins reached the stresses higher than the yield strength. The critical temperature obtained in the numerical model was higher than calculated using EN, due to the introduction to the numerical model excessive simplification. First of all, the criterion of purlin failure was assumed as a beginning of the material plastification. Moreover, numerical model did not include instability problems and sensitivity to imperfection. It did not consider the influence of temperature on boundary conditions either. Therefore, the more accurate model of the connector should be prepared. Based on obtained results, it was pointed out, that the connection between sheeting and a purlin may be destroyed in the fire situation which requires further study.

\section{REFERENCES}

1. Design Manuals, "Steel Buildings in Europe, Single-Storey Steel Buildings, Part 7, Fire engineering”, Arcelor Mittal, 2008.

2. DIFISEK, "Dissemination of Fire Safety Engineering Knowledge", Poznan University of Technology, 2008.

3. Eurocode 3, EN 1993-1-1, Design of steel structures, Part 1-1 General rules and rules for buildings, European Committee for Standardization, 2005. 
4. Eurocode 3, EN 1993-1-2, Design of steel structures, Part 1-2 Structural fire design. European Committee for Standardization for Standardization. 2005.

5. Eurocode 3, EN 1993-1-3, Design of steel structures Part 1-3 General rules - Supplementary rules for coldformed members and sheeting. European Committee for Standardization, 2006.

6. Eurocode 3, EN 1993-1-5, Design of steel structures, Part 1-5 Plated structural elements. European Committee for Standardization, 2005

7. J. M. Frannsen, P. V. Real, "Fire Design of Steel Structures", ECCS Eurocode Design Manuals, 2010.

8. K. Rzeszut, Ł. Polus, "Classes of Cross-Sections of Steel Structural Elements in the Fire Situation", Procedia Engineering 57, 967-976, 2013.

9. M. Maślak, "Fire resistance of steel bar structures", Cracow University of Technology, 2008.

10. M. Szumigała M., Ł. Polus, "Calculation of the critical steel temperature and fire resistance of the steel beam in the segmental barrel vault”, Durability of buildings and structures, Dolnośląskie Educational Publisher, 2012.

\section{LIST OF FIGURES AND TABLES:}

Fig. 1. Lateral and rotational restrained purlin

Rys. 1. Płatew stężona bocznie i na obrót

Fig. 2. The degree of utilization of the purlin depending on the temperature

Rys. 2. Stopień wykorzystania nośności płatwi w zależności od temperatury

Fig. 3. The overall dimensions and the boundary conditions of the sheeting

Rys. 3. Wymiary i warunki brzegowe blachy

Fig. 4. A connector which join sheeting and a purlin

Rys. 4. Łącznik łączący blachę z płatwią

Fig. 5. A surface to surface "hard" contact

Rys. 5. Kontakt "hard" między powierzchniami

Fig. 6. Gravity load

Rys. 6. Obciążenie grawitacyjne

Fig. 7. Boundary conditions of the purlin, $u 1>0$

Rys. 7. Warunki brzegowe dla płatwi, $\mathrm{u} 1>0$

Fig. 8. Steel $\mathrm{S} 350$ and $\mathrm{S} 320, \mathrm{~T}=20^{\circ} \mathrm{C}, 420^{\circ} \mathrm{C}, 450^{\circ} \mathrm{C}, 500^{\circ} \mathrm{C}$

Rys. 8. Stal S350 i S320, $\mathrm{T}=20^{\circ} \mathrm{C}, 420^{\circ} \mathrm{C}, 450^{\circ} \mathrm{C}, 500^{\circ} \mathrm{C}$

Fig. 9. The stresses in the sheeting at the temperature $500{ }^{\circ} \mathrm{C}$ in uplift load case

Rys. 9. Naprężenia w blasze $\mathrm{w}$ temperaturze $500{ }^{\circ} \mathrm{C}$ podczas obciążenia unoszącego

Fig. 10. The stresses in the purlin at the temperature $500{ }^{\circ} \mathrm{C}$ in uplift load case

Rys. 10. Naprężenia w płatwi w temperaturze $500{ }^{\circ} \mathrm{C}$ podczas obciążenia unoszącego

Tab. 1. The data

Tab. 1. Dane

Tab. 2. The calculation

Tab. 2. Obliczenia 


\section{OBLICZENIA PLATWI CIENKOŚCIENNYCH STĘŻONYCH POSZYCIEM W PODWYŻSZONEJ TEMPERATURZE}

Słowa kluczowe: warunki pożarowe, płatwie cienkościenne, blacha trapezowa, numeryczna analiza

\section{STRESZCZENIE:}

Głównym zadaniem projektantów jest zapewnienie bezpieczeństwa ludziom i materiałom znajdującym się w budynkach, zarówno podczas normalnego użytkowania, jak i w momencie wystąpienia pożaru. Płatwie cienkościenne są często stosowane jako elementy konstrukcyjne, ponieważ mają dużą wytrzymałość w stosunku do ciężaru oraz znacząco zmniejszają się koszty związane z transportem i montażem. Jednak, cienkościenne płatwie wykazują bardzo niską odporność na ogień. Metody projektowania elementów konstrukcyjnych w warunkach pożaru są szeroko omówione w dostępnej literaturze. Projektanci mogą łatwo określić temperaturę krytyczną i czas ognioodporności ogniowej elementu. Dla elementów o przekrojach klasy 4 jakimi są płatwie cienkościenne zaleca się przyjmować temperaturę $350^{\circ} \mathrm{C}$ jako temperaturę krytyczną. Oznacza to, że tego rodzaju przekrój teoretycznie traci swoją nośność w tej temperaturze. Założenie to jest bezpieczne i proste do przyjęcia dla projektanta. Wynika ono z następujących problemów: określenie nośności elementów o przekroju klasy 4 jest trudne i pracochłonne, przekroje klasy 4 zagrożone są utratą lokalnej stateczności, przekroje cienkościenne zagrożone są zmianą właściwości stali w strefach gięcia blach podczas formowania, elementy o przekrojach klasy $4 \mathrm{w}$ warunkach pożarowych wciąż nie zostały dostatecznie przebadane. W związku z ostatnim wymienionym problem postanowiono w niniejszej pracy poddać analizie nośność płatwi cienkościennej stężonej poszyciem w podwyższonej temperaturze.

W pierwszym etapie analizowano nośność płatwi współpracujących z poszyciem w podwyższonych temperaturach bazując na formułach analitycznych zawartych w normach europejskich. Autorzy wprowadzili zmiany w równaniach zawartych w EN 1993-1-3 kierując się wytycznymi zawartymi w EN 1993-1-2 i uwzględniając redukcję właściwości materiałowych w warunkach pożarowych takich jak: granica plastyczności, moduł Younga. Zmiany dotyczyły przede wszystkim równań pozwalających projektantowi określić: całkowitą sztywność obrotową podparcia sprężystego płatwi blachą, zastępcze obciążenie boczne, współczynnik zwichrzenia czy nośność samej płatwi. Redukcji wynikającej z wyjątkowej kombinacji zawartej w EN 1990 poddano również obciążenie. Korzystając ze zmodyfikowanych dla warunków pożarowych równań przeprowadzono obliczenia dla przykładowej płatwi. W przykładzie obliczeniowym analizowano dwuprzęsłową płatew o przekroju Z250x68/60x1.5mm stężoną przy pomocy blachy T50x0.7mm. Nośność płatwi została sprawdzona w następujących temperaturach: $20^{\circ} \mathrm{C}, 350^{\circ} \mathrm{C}, 400^{\circ} \mathrm{C}$ oraz $420^{\circ} \mathrm{C}$ zarówno dla obciążenia grawitacyjnego jak i unoszącego. W obliczeniach uwzględniono również obciążenie płatwi siłą normalną. Temperatura w obliczeniach miała redukcyjny wpływ nie tylko na granicę plastyczności, ale również na sztywność połączenia płatwi z blachą. W warunkach normalnych większe wytężenie płatwi otrzymano dla wariantu obciążenia grawitacyjnego, a w warunkach pożarowych dla obciążenia unoszącego. Wynika to z redukcji obciążenia śniegiem podczas pożaru. Dla analizowanej płatwi otrzymano temperaturę krytyczną, po osiągnięciu której traci ona swoją nośność, równą $420^{\circ} \mathrm{C}$. W obliczeniach uwzględniono możliwość zarówno lokalnej jak i globalnej utraty stateczności.

Następnie, dla wybranego przykładu opracowano model numeryczny stosując Metodę Elementów Skończonych w programie Abaqus i elementy powłokowe S4R. Numeryczny model odzwierciedlał pośredni segment lekkiego dachu i składał się z blachy trapezowej i dwóch płatwi cienkościennych. Blacha trapezowa połączona była z płatwiami łącznikami typu belkowego rozmieszczonymi w każdej fałdzie blachy. Ponadto, dla blachy trapezowej i górnej półki płatwi określono powierzchnię kontaktu i jego typ jako „twardy”. W modelu numerycznym geometrię zastąpiono 
elementami skończonymi. W obliczeniach numerycznych przyjęto biliniowe prawa fizyczne dla stali dla analizowanych temperatur: $20^{\circ} \mathrm{C}, 350^{\circ} \mathrm{C}, 400^{\circ} \mathrm{C}$ oraz $450^{\circ} \mathrm{C}$ oraz $500^{\circ} \mathrm{C}$. Parametry fizyczne przyjęto wg norm EN $1993-1-1$ oraz EN 1993-1-2. Obliczenia numeryczne przeprowadzono stosując procedurę Abaqus/Standard z zastosowaniem metody przyrostowej Newtona-Raphsona. Na blasze trapezowej rozłożono w jednym wariancie obciążenie grawitacyjne, a w drugim unoszące. Siła normalna w płatwi została uwzględniona przez wymuszenie przemieszczenia po długości płatwi o adekwatnej do siły wielkości. W modelu odzwierciedlono też podporę płatwi na wiązarze przez zablokowanie w miejscach podpór przemieszczeń w kierunku pionowym i poziomym prostopadłym do długości belki. Jako kryterium zniszczenia przyjęto początek uplastyczniania się płatwi. Obliczenia numeryczne uwzględniały nieliniowość geometryczną. W rezultacie przeprowadzonych obliczeń otrzymano obszerny zbiór wyników. Płatew uplastyczniała się w miejscu połączenia łącznikiem z blachą. Podobnie jak w obliczeniach bazujących na normie analizowana płatew osiąga szybciej temperaturę krytyczną podczas obciążenia unoszącego niż grawitacyjnego. Temperatura krytyczna otrzymana w wyniku analizy numerycznej była wyższa niż uzyskana w wyniku obliczeń wg EN i wynosiła $500^{\circ} \mathrm{C}$, ponieważ zastosowano zbyt prosty model numeryczny, który nie uwzględniał zagadnień niestateczności ogólnej i wpływu temperatury na warunki brzegowe. Ponadto z uwagi na fakt, że w warunkach pożarowych połączenie pomiędzy płatwią i blachą może ulec zniszczeniu, w dalszym etapie pracy należy opracować dokładniejszy model łącznika. 